\title{
Tourism Products Distribution and Large-Scale Retailers
}

\author{
Sabina Riboldazzi*
}

\begin{abstract}
In recent years, tourism retailing has undergone profound changes due, in part, to the emergence of new actors seeking to collaborate with traditional tourism operators while trying to one-up each other's roles and functions. This article aims to analyze the assortment extension of tourism offerings by those large-scale retailers that during the past two decades have succeeded in strengthening their competitive position among tourism supply chain operators. Specifically, this study highlights some of the most important features currently characterising the distribution phase of the tourism supply chain while focusing on the main forms of tourism products retailing adopted by large-scale grocery retailers.
\end{abstract}

Keywords: Global Tourism; Tourism Supply Chain; Tourism Products Distribution; Travel Retailing; Large-Scale Grocery Retailers

\section{Global Tourism and Large-Scale Retailers}

Despite a growing global concern about travel safety and security, tourism is one of the fastest growing industries worldwide.

Since 2000, notwithstanding a number of natural or man-made disasters, such as the 9/11 attacks, the SARS and Ebola outbreaks, the Second Gulf War, the 2004 Indian Ocean earthquake and tsunami, and several soft-target Islamic terror attacks, the tourism industry has steadily grown in terms of both international arrivals \$674 million in 2000 vs. \$1,186 million in 2015 - and international travel receipts earned by destinations worldwide - $\$ 495$ billion in 2000 vs. $\$ 1,260$ billion in 2015 (UNWTO, 2016).

Due to its high degree of dynamism, the tourism market has become appealing to many large-scale retailers seeking to further expand their business activities by exploiting those opportunities that can be found in a fast-paced growing market.

Indeed, large-scale retailers seek to exploit those market opportunities in order to increase revenues in the various geographical areas where they operate. This process of adaptation to market changes has led to increased extension of the assortment qualifying new commercial offerings.

In this regard, large-scale Italian retailers operating in the grocery sector, in the wake of regulatory actions, and following the lead of global retailers, have

* Assistant Professor of Management, University of Milan-Bicocca (sabina.riboldazzi@unimib.it)

Edited by: ISTEI - University of Milan-Bicocca

ISSN: 1593-0319

Riboldazzi, S. (2017). Tourism Product Distribution and Large-Scale Retailers, Symphonya. Emerging Issues in Management (symphonya.unimib.it), 3, 135-147. 
implemented assortment diversification strategies by adding to their offerings extracore products and services typically offered by other sectors.

This study, through analysis of secondary data, aims to analyze the assortment diversification of large-scale grocery retailers related to the offer of tourism products and services. In this regard, large-scale retailers have been strengthening and consolidating their role in the distribution phase of the tourism supply chain where several tourism operators had an already established presence.

Starting from the description of some of the main attributes currently qualifying the distribution phase of the tourism supply chain, this survey will take a closer look at the main forms of tourism products retailing developed by leading large-scale retailers. To this end, we will examine data derived from: 1) websites of leading international and Italian large-scale retailers in the grocery sector ranked by revenues; 2) notable travel and tourism magazines; and 3) in-store observation.

\section{The Distribution Phase of the Tourism Supply Chain}

Different companies operate in the tourism supply chain offering products and services directly or indirectly related to tourism, thereby making tourist attractions in various countries or geographical areas accessible to the general public. Indeed, tourism demand is met thanks to the joint efforts of several enterprises offering transport, accommodation (e.g. hotel, extra-hotel, and on-board), public ancillary services, and recreational bathing activities, including those companies involved in producing and managing man-made or natural attractions and people-gathering events.

Alongside these companies, there can be found a myriad of tourism intermediaries either classified as tour operators, travel agencies, specialised intermediaries (i.e. tour organisers, event incentive organisers, and junket reps), or agents and promoters (Kotler, Bowen \& Makens, 2010).

With regard to the leisure travel market, a key role in marketing channels has always been played by tour operators (wholesalers) and travel agencies (retailers), whose core and traditional business activities come from the creation and development of tourist packages as well as by the sale of tourism services offered by third parties. Thus, according to the traditional linear supply chain model, those tourism companies upstream in the supply chain generally rely on a network of intermediaries, specifically tour operators, which in turn fall back on travel agents to meet the demand.

Since the beginning of the $21^{\text {st }}$ century, the tourism industry has undergone major structural changes; on the one hand, the various companies offering tourism services have been interacting more closely and frequently with each other, involving more and more often tour operators and travel agencies to develop attractive tourism offerings; on the other hand, the different actors of the supply chain have been trying to one-up each other's roles and functions to directly reach the demand source. Alternatively, these companies have started collaborating with "new actors" operating in the tourism market thanks to diversification strategies.

Several factors can be enlisted among the determinants of the changes highlighted above. In particular, the widespread use of the Internet and the adoption of new technologies by tourism operators have both contributed to the creation of 
some important features that are currently shaping the distribution phase of the tourism supply chain. These include: 1) the presence of tourism operators capable of operating through the web and with the aid of new technologies, and in particular the birth and development of online travel agencies (OTAs); 2) the development of aggregates in tourism retailing; and 3) the presence of new physical intermediaries such as large-scale grocery retailers, which are increasingly engaged in the sale of tourism products.

The aforementioned aspects are discussed in further detail below:

1) the presence of tour operators capable of operating through the web and with the aid of new technologies, and in particular the birth and development of online travel agencies (OTAs).

The widespread use of new technologies by tourism companies has greatly enhanced the development of the tourism sector by reshaping the organisational structure of tourism companies as well as their business management functions and relations, thereby optimising management cost and, more generally, increasing corporate value.

In this scenario, the global tourism industry has basically undergone three major technological revolutions; the first one taking place in the 70s, with the creation of the computer reservation system (CRS); the second one starting in the 80s as a result of the expansion of the global distribution system (GDS); and the last one occurring in the second half of the 90s due to the Internet revolution (Buhalis, 1998).

The birth of the first CRS took place in 1964 thanks to a joint effort between American Airlines and IBM leading to the creation of the first Sabre computer reservation system. Likewise, from the late $60 \mathrm{~s}$ to the early $70 \mathrm{~s}$, other airline companies developed their CRSs, such as Apollo, PARS, and Arco.

These first generation CRSs allowed travel agencies to check for flight seat availability of any airline company equipped with such computerised reservation systems. Later on, in addition to connecting demand (i.e. customer), intermediary (i.e travel agencies), and offer (i.e. air carriers), CRSs were further developed to link all other actors of the tourism supply chain, thus clustering the offerings from multiple suppliers such as airlines, hotels, car rentals, cruise lines, etc. This evolution process would then eventually lead to the birth of the GDS, which by the end of the 80 s became a widely spread and consolidated mode of purchase through travel agencies, individual services, or a combination of both. Currently, Amadeus, Galileo, Sabre, and Worldspan are the four major GDSs worldwide.

In Italy, Sigma was the first CRS dedicated to the agency system, founded in 1982 thanks to a joint effort among Alitalia, Ferrovie dello Stato, Tirrenia, and some other small-sised holdings such as STET and BNL, fully endorsed by FIAVET. After the second half of the 80 's, $30 \%$ of the travel agencies operating in Italy were using this system.

During the 90s, one of the many challenges GDSs had to face was represented by the sharp rise of the Internet, which allowed tour operators easy access to the demand source. As a consequence, GDSs were forced to diversify their marketing strategies by integrating traditional offerings with internet services, thereby heavily investing in web-based platforms. 
The rise of the Internet also coincided with the birth of online travel agencies (OTAs), which are powerful search engines used by online customers to book holiday packages and other products as airline tickets or rental cars.

Expedia, launched by Microsoft in 1996, was one of the first OTAs that relied on other booking systems besides its own booking system, which was concomitantly used by other Expedia Group websites.

Thus, with the advent of the Internet, the distribution phase of the tourism supply chain underwent radical changes due to the presence of new actors cooperating with or competing against "traditional actors", which, in turn, were forced to implement web-focused marketing strategies to meet evolving customer demand.

Among the actors operating on the web, we can identify the following categories:

- Traditional tourism intermediaries. These comprise those travel agencies, tour operators or other intermediaries that have expanded their business activities by developing tourism offerings on the web using different strategies. These retailers have scaled up their promotional websites to highquality e-commerce platforms so that they now can sell tourism products and services directly to the customer;

- Tourism service companies. These are represented by suppliers of tourism products and services, and hence include those hotel companies, airlines, car rental companies that sell their tourism offerings online without the help of any tourism intermediaries. These companies, which in the aforementioned case operate through online service providers (i.e. they sell their services on the web), in some cases can also operate through online travel agents. In this instance, besides selling their services online, they offer tourism services by third-parties, thereby acting as channel intermediaries (e.g. airlines offering hotel reservations).

- e-intermediaries. These comprise a new generation of tourist intermediaries selling travel and holiday packages through the web. This category also includes OTAs. Most of these businesses are the result of alliances with actors already operating in the tourism sector; in some cases, these are actors who, thanks to their expertise gained over the years, have established autonomous structures operating on the web.

- Territorial tourism. It refers to public or public-private organisations that promote and manage man-made or natural attractions. In most cases, these organisations sell their services, and therefore cannot be defined as intermediaries; however, in some cases, these agencies combine their online service sales with products developed by other suppliers, thereby becoming virtual business intermediaries.

2) the development of aggregations in tourism retailing.

Since the nineties, the distribution phase of the tourism supply chain has seen the emergence of various forms of aggregation, collaboration, and alliance among tourism retailers, which as such were able to obtain better prices from service providers due to their increased collective buying power. Thus, independent agencies boasting strong local relationships had to start dealing with networks of agencies operating in large geographical areas. These newly formed networks can be divided into the following categories (Gentile, 2012-2013): 
- Property travel agency chains. These are networks of agencies spread across the territory under the control of a single ownership. Generally, network expansion is achieved by either acquiring agencies already present on the market or opening new points of sale in new geographical areas or in geographic areas where the network is already present;

- Associates in participation. According to the association in participation agreement, the associating party attributes to the associated party, upon payment of a previously agreed fee, a stake in the profits and losses of its business. The associated party manages the activity, whereas the associating party retains ownership;

- Partners under a franchise agreement. In this case, the franchisor grants to the franchisee - against payment of a management fee - the right to sell their products using the trademark/ brand of the franchisor along with its expertise and advisory services. Although the franchisee remains the sole owner of the agency, it has to comply with all the obligations stipulated in the franchise agreement (e.g. confidentiality, compliance with the franchisor's quality standards, payment terms, etc.);

- Buying groups and consortia. These entities are formed thanks to trade agreements among independent agencies operating on the territory in order to exploit economies of scale and increase their negotiating power with tour operators or other tourism operators;

- Supercenters. These comprise a tourism network that supplies services not only to the agencies that are members of its network but also to those with which they have stipulated specific trade agreements. Collaboration between agencies is not exclusively based on trading with suppliers, but it also includes other functions such as marketing, finance, information technology, and so on;

- Big Supercenters. When a large supercenter incorporates additional agencies or networks of wholly or partially controlled agencies, it creates a macro-aggregation or big supercenter.

Table 1: Indipendent Network of travel agencies in Italy

\begin{tabular}{|c|c|c|c|}
\hline Independent networks & Type of affiliation & $\begin{array}{c}\text { No. of } \\
\text { agencies }\end{array}$ & $\begin{array}{c}\text { Total No. of } \\
\text { agencies }\end{array}$ \\
\hline Primarete Network & $\begin{array}{l}\text { Business } \\
\text { affiliation }\end{array}$ & 192 & \multirow{9}{*}{$\begin{array}{c}1,031 \\
\text { (out of } 8,500 \\
\text { Italian travel } \\
\text { agencies) }\end{array}$} \\
\hline Giramondo Viaggi & Franchising & 111 & \\
\hline $\begin{array}{l}\text { Free TUR \& Travel/ } \\
\text { Freenet Network }\end{array}$ & Mixed & 104 & \\
\hline One! Travel Network & $\begin{array}{l}\text { Business } \\
\text { affiliation }\end{array}$ & 100 & \\
\hline Le Marmotte & Mixed & 80 & \\
\hline Mister Holiday & $\begin{array}{l}\text { Association in } \\
\text { participation }\end{array}$ & 70 & \\
\hline Travelbuy & $\begin{array}{l}\text { Association in } \\
\text { participation }\end{array}$ & 58 & \\
\hline $\begin{array}{l}\text { Frigerio Viaggi } \\
\text { Network }\end{array}$ & Mixed & 52 & \\
\hline Atlassib Italia & Property & 50 & \\
\hline
\end{tabular}




\begin{tabular}{|l|c|c|}
\hline $\begin{array}{l}\text { Italicaln Tour / We } \\
\text { Mondo }\end{array}$ & Mixed & 39 \\
\hline NGT & Mixed & 37 \\
\hline Viaggiatori e... & $\begin{array}{c}\text { Business } \\
\text { affiliation }\end{array}$ & 35 \\
\hline Hermitage Travel & $\begin{array}{c}\text { Association in } \\
\text { participation }\end{array}$ & 19 \\
\hline Monsieur Vayage & $\begin{array}{c}\text { Association in } \\
\text { participation }\end{array}$ & 15 \\
\hline CIVATURS & Cooperative & 13 \\
\hline Sardinia Collection & $\begin{array}{c}\text { Association in } \\
\text { participation }\end{array}$ & 12 \\
\hline Liberi Tutti & Property & 10 \\
\hline Agenzie 365 & Property & 10 \\
\hline Ocean Viaggi & Property & 7 \\
\hline $\begin{array}{l}\text { Melagodo Viaggi } \\
\text { Network }\end{array}$ & Property & 7 \\
\hline Regent International & Property & 5 \\
\hline Freelastminute & $\begin{array}{c}\text { Association in } \\
\text { participation }\end{array}$ & 5 \\
\hline
\end{tabular}

Source: http://www.network-news.it/, 2015

Table 2: The 8 major tourism retail Groups (macro-aggregations) in Italy

\begin{tabular}{|c|c|}
\hline Groups & Total No. of agencies \\
\hline Geo Travel Network & \multirow{8}{*}{$\begin{array}{c}6,241 \\
\text { (out of } 8,500 \text { Italian } \\
\text { travel agencies) }\end{array}$} \\
\hline Uvet Network e Last Minute Tour & \\
\hline Welcome Travel Group & \\
\hline $\begin{array}{l}\text { Marsupio Group / Fespit / Achille Lauro } \\
\text { NeTravel }\end{array}$ & \\
\hline Gattinoni Mondo di Vacanze & \\
\hline Open Travel Network & \\
\hline Bluvacanze Cisalpina Tours & \\
\hline Robintur Travel Network & \\
\hline
\end{tabular}

Source: http://www.network-news.it/, 2015, 2017

3) the presence of new intermediaries, particularly large-scale grocery retailers, which are increasingly engaging in the sale of tourism products.

In most of the countries where modern distribution has been developed, largescale grocery retailers are now playing an important role in the tourism supply chain due to the inclusion in their offerings of extra-core products and services such as auto fuels, finance, mobile telephony, and tourism, which are offered through different retail formats.

\section{Assortment Extension of Tourism Offerings by Large-Scale Grocery Retailers}

The product of large-scale retailers is represented by the point of sale, which in turn is tightly linked to the format. In particular, commercial offer can be defined as a set of elementary factors (i.e. attributes) combined in different proportions. Each of these attributes corresponds to a specific consumer utility as the presence of more than one attribute enhances the overall satisfaction experienced by the consumer 
with regard to a certain product; among the key attributes, we can find proximity, storage, opening hours, pre-selection, direct information, speed of service, comfort, post-sale, pre-sale and during sales services etc.; the different combinations of elementary factors that make up the service give rise to the format, which represents the product of retail companies.

Each format therefore qualifies for particular attributes including the assortment, which is the core of the market offering.

Large-scale grocery retailers [e.g. Wal-Mart Store, Inc. (U.S.), Costco Wholesale Corporation (U.S.), Carrefour S.A. (France), Schwarz Unternehmens Treuhand KG (Germany), Tesco PLC (UK)] (Deloitte, 2015) generally handle a diversified portfolio of formats (e.g. supermarkets, hypermarkets, discounts, superette, etc.) operating in different commercial areas to meet specific demand needs.

In this regard, in-store assortment composition of each point of sale is often modified with reference to the brand mix of major, followers, domestic, and local brands, as well as private label products, which qualify each specific product line or category. Fourthermore, it can be changed by introducing a new product or product line/category, with consequent changes in assortment depth, variety, and width.

This ongoing process of adaptation to the changing needs of the market has prompted most of the leading retailers to offer categories of products/services far from their core business, which are typically offered by companies operating in other sectors. Indeed, while in the past the assortment extension of large-scale retailers mainly applied to non-food product categories/lines, which integrated or supported core food-type categories, in recent years, the assortment expansion has involved products/services very far from the retailer's original market offering, thus promoting diversification processes in areas traditionally considered unrelated to the core business. It is therefore increasingly common to find, among the market offerings of large-scale grocery retailers, products such as medicines, parapharmaceuticals, and auto fuels, or services related to mobile telephony, insurance, bookings (e.g. books, medical examinations, etc ..), and tourism.

Assortment extension towards new product/service categories by large-scale retailers has been widely analysed in the literature. Some scholars have traced it back to studies on business development strategies, and more specifically on retail product diversification strategies. Others have linked it to studies on innovation in retailing; some others have attributed it to studies on distribution convergence.

In summary, from these studies it is possible to regard assortment extension as a retail development strategy, which increases revenues through diversification of the offer. This diversification is achieved by introducing new products belonging to extra-core categories in existing formats, or by developing new formats dedicated to extra categories. Assortment extension generates distribution innovation in particular with regard to:

- Networking relations with manufacturers, consumers and other partners to effectively and efficiently perform channel functions;

- commercial offering (i.e. the combination of the attributes characterising the format);

- retailing mix levers such as assortment (i.e. aggregation of products offered instore), merchandising (i.e. display of products at the point of sale), private labels (i.e. a company's own brand portfolio), price (i.e. trade margin setting), and communication. 
In particular, when we focus our attention to business development strategies implemented by large-scale retailers in Italy, we can notice that the offer of tourism services has become prominent among the extra-core categories sold by such retailers.

It is possible to highlight common trajectories characterising the actions of largescale grocery retailers with reference to the tourism offer, specifically with regard to formats, offering, and communication and pricing strategies.

Table 3: Assortment extension and travel offer of foreign-owned large-scale retailers companies operating on the Italian market

\begin{tabular}{|c|c|c|c|}
\hline & Carrefour & Auchan & $\mathrm{Lidl}$ \\
\hline $\begin{array}{l}\text { Presence of the } \\
\text { Group } \\
\text { worldwide }\end{array}$ & $\begin{array}{l}\text { Carrefour } \begin{array}{r}\text { group } \\
\text { operates with }\end{array} \\
12,000 \text { stores in more } \\
\text { than } 30 \text { countries. The } \\
\text { group manages } 1,507 \\
\text { hypermarkets, } 3,194 \\
\text { supermarkets, } 7,180 \\
\text { convenience stores, and } \\
\text { 171 cash\&carries. }\end{array}$ & $\begin{array}{l}\text { Auchan Retail is active in } \\
17 \text { countries in Europe, } \\
\text { Asia, and Africa. The } \\
\text { format portfolio of the } \\
\text { Group includes My } \\
\text { Auchan convenience } \\
\text { stores, Auchan City } \\
\text { superstores, Auchan } \\
\text { hypermarkets, and } \\
\text { Auchan supermarkets. }\end{array}$ & $\begin{array}{l}\text { Lidl operates with } \\
\text { over } 10,000 \text { stores } \\
\text { located in } 28 \\
\text { countries in Europe, } \\
\text { America, and Asia. } \\
\text { All Lidl stores are } \\
\text { based on the discount } \\
\text { format. }\end{array}$ \\
\hline $\begin{array}{l}\text { Assortment } \\
\text { extension and } \\
\text { tourism } \\
\text { product/service } \\
\text { offer in the } \\
\text { global and } \\
\text { Italian market }\end{array}$ & $\begin{array}{l}\text { Carrefour offers its } \\
\text { customers a wide range } \\
\text { of convenience services, } \\
\text { including financial, } \\
\text { insurance, travel, photo } \\
\text { and leisure services. } \\
\text { Carrefour has extended } \\
\text { its assortment to energy, } \\
\text { motor fuels, and } \\
\text { pharmaceuticals. } \\
\text { Regarding the tourism } \\
\text { product/service offer, } \\
\text { every year, more than } \\
\text { 450,000 customers in } \\
\text { France go on holiday } \\
\text { with Carrefour Voyages. } \\
\text { French customers can } \\
\text { book tickets for more } \\
\text { than 60,000 events at } \\
\text { 550 dedicated in-store } \\
\text { areas or directly online. } \\
\text { In Spain, in only three } \\
\text { years, Carrefour Viajes } \\
\text { has become the } \\
\text { country's third-largest } \\
\text { network, currently } \\
\text { boasting more than } 500 \\
\text { agencies. The service } \\
\text { available in Belgium } \\
\text { has also been expanded, } \\
\text { and now it includes } \\
\text { ticket bookings for a } \\
\text { number of amusement } \\
\text { parks ins. } \\
\text { (www.caffefour.com). } \\
\text { In Italy, the travel offer } \\
\text { is marketed under the } \\
\text { brand name of } \\
\text { Carrefour Viaggi, which } \\
\text { allows on-line booking } \\
\text { through its website } \\
\text { TravelNow. }\end{array}$ & $\begin{array}{l}\text { Auchan offers various } \\
\text { services to its customers } \\
\text { including mobile } \\
\text { telephony, financing, } \\
\text { security, photo printing, } \\
\text { transport fuel sales and } \\
\text { travel. With regard to the } \\
\text { assortment extension } \\
\text { towards tourism products } \\
\text { and services, Auchan } \\
\text { operates in Italy under the } \\
\text { brand name of AVacanze. } \\
\text { This brand acquires } \\
\text { slightly different } \\
\text { connotations depending } \\
\text { on the country where it } \\
\text { operates. For instance, in } \\
\text { the French market, the } \\
\text { brand name is Auchan } \\
\text { Vayage. AVacanze is a } \\
\text { travel agency and tour } \\
\text { operator dedicated to } \\
\text { Auchan customers in the } \\
\text { Italian market. It is } \\
\text { managed by Eurotours } \\
\text { Italia Srl licensed to } \\
\text { Eurotours Italia Travel } \\
\text { Marketing, a leader in the } \\
\text { tourism sector. AVacanze } \\
\text { allows its customers to } \\
\text { book holiday packages, } \\
\text { rent cars, reserve airport } \\
\text { parking, book cruises, } \\
\text { organise tours, and } \\
\text { purchase airplane or } \\
\text { ferry transfers. Thanks to } \\
\text { Eurotours management, } \\
\text { customers can choose } \\
\text { from over 10,000 travel } \\
\text { solutions. }\end{array}$ & $\begin{array}{l}\text { Lidl offers } 6,246 \text { of } \\
\text { food and non-food } \\
\text { product lines. } \\
\text { Regarding the } \\
\text { assortment extension, } \\
\text { it is noteworthy the } \\
\text { availability of photo } \\
\text { printing and travel } \\
\text { services also in the } \\
\text { Italian market. } \\
\text { Regarding the travel } \\
\text { offer, this Group } \\
\text { offers the possibility } \\
\text { to book trips for the } \\
\text { following categories: } \\
\text { mountain, sea, nature/ } \\
\text { rural tourism, city } \\
\text { sightseeing, lakes, } \\
\text { markets, wellness\& } \\
\text { spa resorts, cruises, } \\
\text { theme holidays, } \\
\text { coach tours, last } \\
\text { minute travel, flight } \\
\text { plus hotel packages, } \\
\text { travel for market } \\
\text { segments such as } \\
\text { trips with children or } \\
\text { animals, In } \\
\text { destinations and } \\
\text { young couples. In } \\
\text { Italy, Lidl offers the } \\
\text { opportunity to buy } \\
\text { online trips through } \\
\text { its website } \\
\text { lidlviaggi.it. This } \\
\text { service avails itself of } \\
\text { the collaboration with } \\
\text { Ignas Tour, an Italian } \\
\text { tour operator. }\end{array}$ \\
\hline
\end{tabular}

Source: www.carrefour.it ;www.carrefour.com; www.auchan-retail.com; www.auchan.it; www.vacanze.auchan.it; Auchan Retail, Activity Report, 2016;www.lidl.com; www.lidl.it; www.lidlviaggi.it. 
Table 4: Tourism market offerings by some large-scale Italian retailers

\begin{tabular}{|c|c|c|}
\hline & $\begin{array}{l}\text { Group presence in the Italian } \\
\text { market }\end{array}$ & $\begin{array}{c}\text { Some attributes relative to the } \\
\text { tourism offer }\end{array}$ \\
\hline Coop & $\begin{array}{l}\text { In Italy, the Coop Group boasts } \\
102 \text { hypermarkets, } 701 \text { large } \\
\text { cooperative supermarkets, and } \\
389 \text { small and medium-sised } \\
\text { cooperative supermarkets, } \\
\text { generating revenues of } \\
€ 12,420.7 \text { million. }\end{array}$ & $\begin{array}{l}\text { Thanks to tour operators relying } \\
\text { on cooperative capital, } \\
\text { members can purchase } \\
\text { customised travel packages at } \\
\text { affordable prices from travel } \\
\text { agencies or online. In the } \\
\text { tourism sector, some large } \\
\text { cooperatives operate through } \\
\text { two chains of travel agencies, } \\
\text { namely Robintur and New } \\
\text { Planetarium,which are present } \\
\text { in some Italian regions. With } \\
\text { over 90 property agencies, } \\
\text { Robintur SpA is the largest } \\
\text { direct travel agency in Italy } \\
\text { arising from the merger } \\
\text { between Robintur and } \\
\text { Planetario Viaggi, both } \\
\text { belonging to the Coop group } \\
\text { Alliance 3.0. }\end{array}$ \\
\hline Esselunga & $\begin{array}{l}\text { In 2015, the Esselunga Group } \\
\text { achieved sales of } € 7,300 \\
\text { million, an increase of } 4.3 \% \\
\text { compared to 2014. Esselunga } \\
\text { operates on the domestic } \\
\text { territory with Esselunga } \\
\text { supermarkets, } \\
\text { superstore and Esselunga } \\
\text { Sottocasa (i.e. a type of } \\
\text { convenience store). }\end{array}$ & $\begin{array}{l}\text { Servizio Viaggi } \\
\text { (www.servizioviaggi.it) is the } \\
\text { exclusive tour operator service } \\
\text { and travel agency for Fidaty } \\
\text { Esselunga card holders, } \\
\text { managed by Eurotours Italia } \\
\text { Travel Marketing, which } \\
\text { specialises in direct booking of } \\
\text { trips to sea, lake, mountain, } \\
\text { countryside, art city, or world } \\
\text { capitals at highly competitive } \\
\text { prices. Eurotours Italia Travel } \\
\text { Marketing selects special } \\
\text { holiday packages, cruises, } \\
\text { ferries, car rentals, and airport } \\
\text { parking at discounted rates for } \\
\text { Esselunga customers in } \\
\text { collaboration with the best tour } \\
\text { operators. }\end{array}$ \\
\hline Eurospin & $\begin{array}{l}\text { Eurospin is the largest Italian } \\
\text { discount with over } 1,000 \\
\text { points of sale in Italy and } \\
\text { Slovenia. }\end{array}$ & $\begin{array}{l}\text { Eurospin sells online travels } \\
\text { under the brand name of } \\
\text { Eurospin Travel. Eurospin New } \\
\text { Business Srl is the name of the } \\
\text { company responsible for the } \\
\text { travel offer. Travel destinations } \\
\text { can be grouped into the } \\
\text { following categories: } \\
\text { mountains, spa\&wellness, } \\
\text { cities, Christmas markets, } \\
\text { lakes\&countryside, theme } \\
\text { holidays, tours, sea abroad, and } \\
\text { cruises. }\end{array}$ \\
\hline Iper & $\begin{array}{l}\text { It belongs to the Finiper } \\
\text { Group, which operates } \\
\text { predominantly in the field of } \\
\text { large-scale retailing. The } \\
\text { Group's activities are divided } \\
\text { into three major areas: } \\
\text { hypermarkets with the brand } \\
\text { names of Iper and La Grande I, } \\
\text { UNES supermarkets, and real } \\
\text { estate activities. }\end{array}$ & $\begin{array}{l}\text { Travel Advantages is the } \\
\text { service managed by Eurotours } \\
\text { Italia Travel Marketing } \\
\text { exclusive to Carte Vantaggi } \\
\text { Iper cardholders. The offer is } \\
\text { based on booking of holiday } \\
\text { stays or holiday packages, } \\
\text { cruises, ferries, car rentals and } \\
\text { other tourist services at } \\
\text { discounted prices. }\end{array}$ \\
\hline
\end{tabular}

Source: Coop, Dodicesimo rapporto sociale nazionale della cooperazione di consumatori 2015 e nota sui principali impegni 2016; www.e-coop.it; www.robintour.it; www.esselunga.it;www.servizioviaggi.it; www.gdonews.it; www.eurospin.it; www.eurospin-viaggi.it; www.iper.it; www.vantaggitravel.it. 
With regard to channels/formats managed by large-scale retailers for the sale of tourism products can be highlighted that some retailers use, combine and/or integrate across markets the following retail formats:

- Online sales by means of corporate websites also used for the sale of grocery products or websites dedicated exclusively to the tourism offering;

- Sales in brick-and-mortar stores, and specifically in:

- $\quad$ specialised stores dedicated to the sale of tourism products. In this case, the portfolio format of the retailer (e.g. hypermarkets, supermarket, superstore, etc.) acquires a new specialised format, that is the travel agency;

- exhibition areas located in existing formats (e.g. hypermarkets, supermarkets, etc.). In this case, considering the overall offer of the store, both core and peripheral offerings are modified; the core offering is enriched because a new product category (i.e. tourism services) is being offered; the peripheral offering is improved thanks to the introduction of ancillary services (i.e. pre-sale, sale, and postsale) related to the sale of tourism products/services; therefore, the overall offer by large-scale retailers becomes increasingly despecialised due to the addition of tourism services to the traditional product categories sold in the store (e.g. food, household, pet products, etc.).

When we take a closer look at the composition of the tourism offering in largescale retailing, we can find many similarities with that of traditional travel agencies, which generally consists of the following:

- airline, maritime, and train ticket booking;

- holiday packages offered by tour operators;

- hotel services;

- booking of other services such as car rental, parking, and tickets for shows or cultural and sports events.

Large-scale retail tourism offering is often supported by aggressive communication strategies based on promotion campaigns highlighting intracategory price competitiveness. In particular, thanks to cross-promotion initiatives, fidelity card holders receive coupons commensurate with the amount of money they spend to buy grocery. These coupons can then be used to obtain a discount on a single purchase of tourism products. Furthermore, large-scale retailers generally develop communication strategies by combining traditional media (e.g. radio, newspapers, in-store signage, etc.) with innovative media (e.g. websites, QrCode, in-store video, etc.) in order to customise the communication.

With reference to price policies, large-scale grocery retailers implement dynamic and competitive pricing strategies that allow them to acquire new customers and develop customer relations. Consequently, retailers are generally able to make up for the low profits deriving from the sale of discounted tourism products/services thanks to increased revenues arising from grocery sales to loyal customers, or more generally to occasional customers who, while visiting travel agencies nearby the point of sale or located in inner areas of the point of sale, decide to purchase products or services of different categories. 
It should also be pointed out that the vast majority of tourism retailers analysed in this survey tend to form alliances with operators specialised in the tourism sector (e.g. main tour operators, travel agency chains, and online tour operators) to take advantage of economies of scale, scope, and specialisation, otherwise unattainable, which allow them to optimise their tourism offering management. In contrast, largescale grocery retailers, in order to optimise retail mix management associated with the tourism category, rely on the knowledge, skills, relationships, technologies and, more generally, on those sophisticated management techniques that the Groups they belong to have developed over time, thereby achieving high levels of managerial effectiveness/efficiency through the integration of cross-category strategies. Moreover, several determinants developed over time by retailers during their business activities can tip the balance in favor of positive results in the sale of tourism products and services. These include the following:

- a consolidated customer base that can also increase the demand for the tourism category;

- a wide network of points of sale spread across the territory that can promote and sell tourism-related services;

- the availability of corporate websites for e-commerce that can also be used for the sale of tourism products/services;

- the extent of brand awareness and image which can generate more revenues from tourism products/services thanks to brand recognition;

- customer information processing that can help generate customised tourism offerings.

Lastly, it should be noted that the development of tourism offerings by retailers results in retail format diversification, thereby making them perceived as innovators. As a result, the company-customer bond becomes increasingly stronger, improving the overall profitability of the enterprise.

\section{Conclusions}

In recent years, the tourism industry has undergone major changes. In particular, the emergence of the Internet and the introduction of new technologies have changed the structure and organisation of tourism retailing, which is now characterised by the development of strategic alliances and the presence of new actors such as online operators and large-scale retailers.

Indeed, the latter have recently expanded their assortment by offering attractive tourism products and services. The ability of large-scale retailers to sell competitive tourism offerings is mostly due to the development of partnerships with specialised operators already present on the market. Furthermore, large-scale retailers have been able to optimise retail mix management related to tourism offerings thanks to the expertise, relationships, technologies, and sophisticated management techniques their Groups have accrued over time selling other product categories. In this regard, online sales, competitive pricing, and effective communication policies through new technologies and advanced costumer information processing, along with the brand awareness, have all proven essential in helping retailers develop value-added services also in the tourism sector to support their sales worldwide. 


\section{Bibliography}

Bakos, Y. (2001). The Emerging Landscape for Retail E-Commerce, The Journal of Economic Perspectives, 15 (1), 69-80. http://dx.doi.org/10.1257/jep.15.1.69

Belleflamme, P., Neysen, N. (2009). Coopetition in Infomediation: General Analysis and Application to e-Tourism. In: Matias, Á., Nijkamp, P., Sarmento M., (eds) Advances in Tourism Economics. Physica-Verlag HD, 217-234. https://doi.org/10.1007/978-3-7908-2124-6_14

Bellini, N., Brondoni, S.M. (2016). Ouverture de Global Tourism in Global Markets, Symphonya. Emerging Issues in Management (symphonya.unimib.it), 1, 1-6. http://dx.doi.org/10.4468/2016.1.010uveture

Brondoni, S.M. (2008). Market-Driven Management, Competitive Space and Global Networks, Symphonya. Emerging Issues in Management (symphonya.unimib.it), (1), 14-27. http://dx.doi.org/10.4468/2008.1.02brondoni

Brondoni, S.M. (2012). Innovation and Imitation: Corporate Strategies for Global Competition, Symphonya. Emerging Issues in Management (symphonya.unimib.it), (1), 10-24. http://dx.doi.org/10.4468/2012.1.02brondoni

Brondoni, S.M. (2016). Global Tourism Management. Mass, Experience and Sensations Tourism, Symphonya. Emerging Issues in Management (symphonya.unimib.it), 1, 7-24. http://dx.doi.org/10.4468/2016.1.02brondoni

Brondoni, S.M., Franzoni, S. (2016). Ouverture de 'Market-Driven Management in Global Tourism', Symphonya. Emerging Issues in Management (symphonya.unimib.it), 2, 1-6. http://dx.doi.org/10.4468/2016.2.01ouverture

Buhalis, D. (1998). Strategic Use of Information Technologies in the Tourism Industry, Tourism Management, 19 (5), 409-421.

Coles, T., Hall, C.M. (eds). (2008). Tourism and International Business, Routledge, London.

Cooper, C., Fletcher, J., Fyall, J., Gilbert, D., Wanhill, S. (1999). Tourism Principles and Practices, Prentice-Hall, Upper Sadle River.

Deloitte. (2015). Top 10 Global Retailers Show Modest Growth in 2014.

Dupuis, M. (2000). Retail Innovation: Towards a Framework of Analysis, International EAERCD Conference on Retail Innovation, Barcelona: ESADE.

Gentile, R. (2012-2013). La distribuzione turistica in Italia: da bottega a grande distribuzione organizzata, un'evoluzione durata vent'anni, in E. Becheri, G. Maggiore, Rapporto sul turismo italiano. IRAT.

Giaglis, G.M., Klein, S., O'Keefe, R.M. (2002). The Role of Intermediaries in Electronic

Marketplaces: Developing a Contingency Model, Information Systems Journal, 12 (3), 231-246. http://dx.doi.org/10.1046/j.1365-2575.2002.00123.x

Gnecchi, F. (2009). Market-Driven Management, Market Space and Value Proposition, Symphonya. Emerging Issues in Management (symphonya.unimib.it), (2), 33-45. http://dx.doi.org/10.4468/2009.2.04gnecchi

Javalgi, R., Ramsey, R. (2001). Strategic Issues of E-commerce as an Alternative Global Distribution System, International Marketing Review, $18 \quad$ (4), 376-391. http://doi.org/10.1108/02651330110398387

Kim, D.J., Kim, W.G., Ha, J.S. (2007). A Perceptual Mapping of Online Travel Agencies and Preference Attributes, Tourism Management, $28 \quad$ (2), 591-603. http://doi.org/10.1016/j.tourman.2006.04.022

Kim, W.G., Lee, H.Y. (2004). Comparison of Web Service Quality Between Online Travel Agencies and Online Travel Suppliers, Journal of Travel \& Tourism Marketing, 17 (2-3), 105-116. http://dx.doi.org/10.1300/J073v17n02_09

Kotler, P., Bowen, J.T., Makens, J.C. (2010). Marketing for Hospitality and Tourism, Prentice Hall.

Law, R., Leung, R. (2000). A Study of Airline's Online Reservation Services on the Internet, Journal of Travel Research, 39 (2), 202-211. http://dx.doi.org/10.1177/004728750003900210

Martinelli, E. (2012). Distributori Grocery in Convergenza. Esperienze a Confronto. Milan: Franco Angeli. 
Morrison, A., Thomas, R. (1999). The Future of Small Firms in the Hospitality Industry, International Journal of Contemporary Hospitality Management, 11 (4), 148-154. http://doi.org/10.1108/09596119910263531

Riboldazzi, S. (2005). Global Retailers and Competitive Customer Value, Symphonya. Emerging Issue in Management (symphonya.unimib.it), 2, 77-87 http://dx.doi.org/10.4468/2005.2.07riboldazzi

Riboldazzi, S. (2010). Retail Policies in the Global Gasoline Market, Symphonya. Emerging Issues in Management (symphonya.unimib.it), 1, 86-101. http://dx.doi.org/10.4468/2010.1.09riboldazzi

Riboldazzi, S. (2015). Global Markets and Development Policies in Large-Scale Retailers, Symphonya. Emerging Issues in Management (symphonya.unimib.it), 5, 8-28. http://dx.doi.org/10.4468/2015.5.02riboldazzi

Risso, M. (2010). Large Retailers' Financial Services, Symphonya. Emerging Issues in Management (symphonya.unimib.it), 1, 65-75. http://dx.doi.org/10.4468/2010.1.07risso

Ryan, C., Cliff, A. (1997). Do Travel Agencies Measure Up to Customer Expectation? An Empirical Investigation of Travel Agencies' Service Quality as Measured by SERVQUAL, Journal of Travel \& Tourism Marketing, 6 (2). 1-31, http://dx.doi.org/10.1300/J073v06n02_01

Salvioni, D. M. (2016). Hotel Chains and the Sharing Economy in Global Tourism, Symphonya. Emerging Issues in Management (symphonya.unimib.it), 1, 31-44. http://dx.doi.org/10.4468/2016.1.04salvioni

Thakran, K., Verma, R. (2013). The Emergence of Hybrid Online Distribution Channels in Travel, Tourism and Hospitality, Cornell Hospitality Quarterly, 54(3), $240 \quad-247$. http://dx.doi.org/10.1177/1938965513492107

UNWTO. (2016). Tourism Highlights.

Wang, S., Wainman, C. (2004). E-Business Adoption by Travel Agencies: Prime Candidates for Mobile e-Business, International Journal of Electronic Commerce, 8 (3), 3-63.

Zhang, X., Song, H., Huang, G. Q. (2009). Tourism Supply Chain Management: A New Research Agenda, Tourism Management, 30 (3), 345-358.

http://dx.doi.org/10.1016/j.tourman.2008.12.010 